\title{
Adrenalectomy impairs insulin-induced hypophagia and related hypothalamic changes
}

\author{
Ernane Torres Uchoa1,2, Paula Beatriz Marangon1, Rodrigo Rorato1,3, Silvia Graciela Ruginsk ${ }^{1,4}$, \\ Lucas Kniess Debarba', Jose Antunes-Rodrigues ${ }^{1}$ and Lucila L K Elias ${ }^{1}$ \\ 'Department of Physiology, School of Medicine of Ribeirao Preto, University of Sao Paulo, Sao Paulo, Brazil \\ 2Department of Physiological Sciences, State University of Londrina, Londrina, Brazil \\ 3Biotechnology Unit, University of Ribeirao Preto, Ribeirao Preto, Brazil \\ ${ }^{4}$ Department of Physiological Sciences, Biomedical Sciences Institute, Federal University of Alfenas, Alfenas, Brazil
}

Correspondence should be addressed to E T Uchoa: ernane_uchoa@yahoo.com.br

\begin{abstract}
Adrenalectomy (ADX) induces hypophagia and glucocorticoids counter-regulate the peripheral metabolic effects of insulin. This study evaluated the effects of ADX on ICV (lateral ventricle) injection of insulin-induced changes on food intake, mRNA expression of hypothalamic neuropeptides (insulin receptor (InsR), proopiomelanocortin, cocaine and amphetamine-regulated transcript (Cart), agouti-related protein, neuropeptide $Y$ (Npy) in the arcuate nucleus of the hypothalamus (ARC), corticotrophin-releasing factor in the paraventricular nucleus of the hypothalamus) and hypothalamic protein content of insulin signaling-related molecules (insulin receptor substrate (IRS) 1, protein kinase $B(A K T)$, extracellular-signal-regulated kinase (ERK1/2), c-Jun N-terminal kinase (JNK), protein tyrosine phosphatase-1B (PTP1B) and T cell protein tyrosine phosphatase (TCPTP)) Compared with sham animals, ADX increased the hypothalamic content of pJNK/JNK, PTP1B and TCPTP, as well as decreased mRNA expression of Ins $R$, and corticosterone (B) treatment reversed these effects. Insulin central injection enhanced hypothalamic content of pAKT/AKT and Cart mRNA expression, decreased Npy mRNA expression and food intake only in sham rats, without effects in ADX and ADX + B rats. Insulin did not alter the hypothalamic phosphorylation of IRS1 and ERK1/2 in the three experimental groups. These data demonstrate that ADX reduces the expression of Ins $R$ and increases insulin counter-regulators in the hypothalamus, as well as ADX abolishes hypophagia, activation of hypothalamic AKT pathway and changes in Cart and Npy mRNA expression in the ARC induced by insulin. Thus, the higher levels of insulin counter-regulatory proteins and lower expression of InsR in the hypothalamus are likely to underlie impaired insulininduced hypophagia and responses in the hypothalamus after ADX.
\end{abstract}

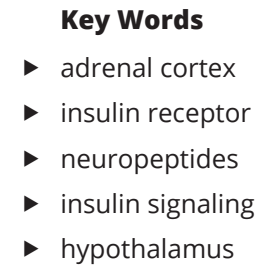

Journal of Endocrinology (2019) 242, 125-138

\section{Introduction}

Bilateral adrenalectomy in rodents is a well-established experimental model to investigate the mechanisms underlying changes on energy homeostasis, as hypophagia and body weight loss, which are also classical symptoms observed in primary adrenal insufficiency in humans
(Freedman et al. 1985, Oelkers 1996, Uchoa et al. 2009a,b). The hypophagic effect induced by ADX is associated with changes in the expression of hypothalamic neuropeptides involved in the regulation of food intake, as evidenced by increases in the expression of the anorexigenic 
neuropeptide corticotrophin-releasing factor (Crf) in the paraventricular nucleus of the hypothalamus (PVN) (Uchoa et al. 2010) and reduction in the expression of the orexigenic neuropeptides neuropeptide $\mathrm{Y}(\mathrm{N} p y)$ and agouti-related protein (Agrp) in the arcuate nucleus of the hypothalamus (ARC) (Uchoa et al. 2012).

In addition to glucocorticoids, insulin is another peripheral factor that acts in the central nervous system (CNS) to regulate energy homeostasis (Plum et al. 2005). Insulin secretion is proportional to the body weight and adiposity and is stimulated by food intake (Trayhurn et al. 1995, Peiser et al. 2000, Germano et al. 2008, Uchoa et al. 2010, Panchal et al. 2011). Plasma insulin access the brain by penetrating the blood-brain barrier through a receptor mediator and saturable transporter (Baura et al. 1993). In the CNS, insulin receptors (InsRs) are expressed in the hypothalamus, especially in the nuclei involved in the regulation of energy homeostasis, as ARC, PVN, dorsomedial $(\mathrm{DMH})$ and ventromedial $(\mathrm{VMH})$ nuclei of the hypothalamus (van Houten et al. 1980, Werther et al. 1987, Unger et al. 1989). Indeed, insulin injection in different regions of the hypothalamus, as well as in the lateral or third ventricle, reduces food intake and body weight gain (Brief \& Davis 1984, McGowan et al. 1990, Rorato et al. 2017). It is known that phosphatidylinositol 3-kinase (PI3K) and mitogen-activated protein kinase/ extracellular-signal-regulated kinase (MAPK/ERK) signaling pathways mediate insulin effects in the CNS. The PI3K pathway is responsible for most metabolic effects of insulin, while the MAPK pathway is involved in the regulation of gene expression and, together with the PI3K pathway, in the control of cell growth and differentiation (De Meyts 2000). In addition, insulininduced hypophagia is associated with changes in the expression of hypothalamic neuropeptides (Schwartz et al. 1992, Benoit et al. 2002, Li et al. 2002, Chan et al. 2005, Honda et al. 2007). On the other hand, it is known that molecules that counter-regulate insulin signaling are more activated or expressed in different models of obesity and insulin resistance, including protein tyrosine phosphatases (PTPs), protein tyrosine phosphatase 1B (PTP1B) and T cell protein tyrosine phosphatase (TCPTP) and c-Jun-N-terminal kinase (JNK) (Belgardt et al. 2010, $\mathrm{Xu}$ et al. 2014).

Additionally, the interplay between insulin and glucocorticoids has been extensively explored, since peripheral metabolic effects of insulin are counterregulated by glucocorticoids and ADX enhances insulin sensitivity in peripheral tissues (Caro \& Amatruda 1982, Weinstein et al. 1995, Haluzik et al. 2002, Long et al. 2003).
Since few studies have reported the role of glucocorticoids on the central effects of insulin on energy homeostasis, the present study was designed to evaluate the effects of ADX on central injection of insulin-induced changes on food intake, hypothalamic neuropeptides and insulin signaling molecules.

\section{Experimental procedures}

\section{Animals}

Male Wistar rats, from the Animal Facility of the Campus of Ribeirao Preto, University of Sao Paulo, Brazil, weighing $230-280 \mathrm{~g}$, were individually housed at a controlled temperature $\left(23 \pm 2^{\circ} \mathrm{C}\right)$ and light-darkness cycle (light from 06:00 to 18:00 h). Animals had ad libitum access to pelleted rat chow and water, unless otherwise specified. To improve habituation to the laboratory environment, the rats were handled daily for 7 days preceding the experiments. All experimental procedures were conducted between 14:00 and 18:00 $\mathrm{h}$ and were approved by the Ethical Committee for Animal Use of the School of Medicine of Ribeirao Preto, University of Sao Paulo, Brazil (protocol number 092/2011).

\section{Intracerebroventricular (icv) cannulation and bilateral adrenalectomy}

Animals were deeply anesthetized with intraperitoneal (IP) injections of a mixture of ketamine $(72 \mathrm{mg} / \mathrm{kg})$ and xylazine $(11.2 \mathrm{mg} / \mathrm{kg})$, administered as a cocktail consisting of $45 \%$ ketamine $(100 \mathrm{mg} / \mathrm{mL}), 35 \%$ xylazine $(20 \mathrm{mg} / \mathrm{mL})$ and $20 \% 0.15 \mathrm{M} \mathrm{NaCl}$ at a dose of $0.16 \mathrm{~mL} / 100 \mathrm{~g}$ of body weight. Then, animals were placed in a stereotaxic instrument (Kopf, model 900) with bregma and lambda in a horizontal plane. A stainless-steel guide cannula ( $10.0 \mathrm{~mm}$ long, $0.6 \mathrm{~mm}$ o.d., $0.4 \mathrm{~mm}$ i.d.) was implanted into the right lateral ventricle using coordinates from the atlas of Paxinos and Watson (1997): $0.6 \mathrm{~mm}$ caudal to bregma, $1.5 \mathrm{~mm}$ lateral to the sagittal suture and $3.5 \mathrm{~mm}$ below the skullcap. The cannula was fixed to the cranium using dental acrylic resin and two jeweler's screws. A 30-gauge metal obturator filled the cannula except during the injections. Cannula placement was verified by the influx of saline $(\mathrm{NaCl} 0,9 \%)$, through a saline column, during the cannula implantation surgery.

Immediately after icv surgery, animals were subjected to bilateral ADX and sham surgeries. Surgeries were performed via a dorsal midline approach with a single incision in the skin and small bilateral incision through 
the muscle layer at the angle between the last rib and vertebral column. In adrenalectomized rats, the kidney was readily seen, and the adrenal gland found at the top of the kidney was visualized and totally removed. Animals were given $0.9 \%$ saline with $0.5 \%$ ethanol, without (ADX) or with corticosterone diluted in $0.5 \%$ ethanol at a concentration of $25 \mathrm{mg} / \mathrm{L}(\mathrm{ADX}+\mathrm{B})$ (Uchoa et al. 2009a). Sham-operated animals underwent similar surgical procedures, but the adrenal glands were not removed, and animals were given tap water with $0.5 \%$ ethanol to drink. After surgeries, the rats received a prophylactic injection of penicillin $(50,000 \mathrm{U}$, i.m.) and could recover for 7 days, during which they were handled daily. Plasma corticosterone levels were determined by radioimmunoassay (Castro et al. 1995).

\section{Microdissection, total RNA isolation and semi-quantitative real-time PCR}

A set of sham, $\mathrm{ADX}$ and $\mathrm{ADX}+\mathrm{B}$ rats was killed by decapitation for the determination of the relative expression of insulin receptor (InsR) mRNA in the hypothalamus (PVN, ARC, VMH and DMH). Another set of experimental animals was submitted to vehicle or insulin administration, as previously described, and decapitated $120 \mathrm{~min}$ after for the determination of the relative mRNA expression of neuropeptides involved in the regulation of food intake in the PVN and ARC. The brains were collected under RNAse-free conditions and kept at $-80^{\circ} \mathrm{C}$ until total RNA extraction. The target brain structures were obtained in a cryostat from two consecutive thick coronal sections $(1500 \mu \mathrm{m}$ each, from coordinates $0.6-2.1 \mathrm{~mm}$ and $2.1-3.6 \mathrm{~mm}$ posterior to bregma), according to the rat brain atlas (Paxinos \& Watson 1997). The PVN and ARC were isolated from the first and second thick sections, respectively, using a stainlesssteel punch needle with $1.5 \mathrm{~mm}$ of internal diameter. $\mathrm{DMH}$ and VMH were punched from the second section, using a stainless-steel punch needle with $1.0 \mathrm{~mm}$ of internal diameter. Tissue samples were transferred to a microtube containing RNA later reagent (Ambion, USA) until RNA isolation. Total RNA was isolated from each micropunched hypothalamic tissue sample using TRIzol reagent (Invitrogen $®$ ) according to the manufacturer's protocol. The RNA concentration in each sample was determined using a UV spectrophotometer, and 500ng of RNA were used for cDNA synthesis using the HighCapacity cDNA Reverse Transcription Kit (Applied Biosystems). Quantitative real-time PCR was performed using an Applied Biosystems 7500 real-time PCR system.
The TaqMan® Gene Expression Assays (Applied Biosystems) used in this study were Rn00690703_m1 (Insulin receptor), Rn 01431703_g1 (Agrp), Rn 01410145_m1 (Npy), Rn 00595020_m1 (Pomc), Rn 00567382_m1 (Cart) and Rn 01462137_m1 (Crf). Each PCR reaction was performed in duplicate. Water (instead of cDNA) was used as a negative control. Housekeeping gene (beta actin) was run for each cDNA sample. The determination of gene transcript levels in each sample was obtained by the $\Delta \Delta \mathrm{CT}$ method. For each sample, the threshold cycle $(\mathrm{Ct})$ was determined and normalized to the average of the housekeeping genes ( $\Delta \mathrm{Ct}=\mathrm{C}$ tUnknown $-\mathrm{CtHousekeeping} \mathrm{genes).} \mathrm{The} \mathrm{fold-}$ change of mRNA expression in the unknown sample

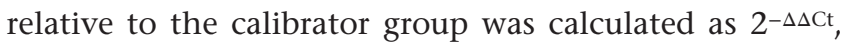
where $\Delta \Delta \mathrm{Ct}=\Delta \mathrm{ctUnknown}-\Delta \mathrm{CtCalibrator}$ (Livak \& Schmittgen 2001). Housekeeping genes were used to normalize the amount of RNA used in each reaction. To get the relative quantification, described in arbitrary units, appropriate calibrator groups were used as control to compare (1) the effect of treatment (vehicle or insulin) on mRNA expression in each group (sham, ADX, ADX +B); (2) the effect of glucocorticoid sufficiency or not (sham, $\mathrm{ADX}, \mathrm{ADX}+\mathrm{B}$ ) on mRNA expression in vehicle- and insulin-treated animals. To attain the first and second analysis, the respective vehicle group and sham-vehicle or sham-insulin group were used as calibrator. Data are shown as mRNA expression relative to the calibrator group, respectively.

\section{Western blotting analysis of medial basal hypothalamus/immunoblot analysis}

Hypothalamic fragments were dissected out (thickness: $2.7 \mathrm{~mm}$ ) from an area $1.0 \mathrm{~mm}$ lateral to the midline at the anterior border of the optic chiasm and the anterior border of the mammillary bodies. The medial basal hypothalamus samples were extracted using Triton-X 100 (1\%), Tris-HCl pH $7.4(100 \mathrm{mM})$, sodium pyrophosphate $(100 \mathrm{mM})$, sodium fluoride $(100 \mathrm{mM})$, EDTA $(10 \mathrm{mM})$, sodium orthovanadate $(10 \mathrm{mM})$, PMSF $(2 \mathrm{mM})$, aprotinin $(0.2 \mathrm{mg} / \mathrm{mL})$ and leupeptin $(0.2 \mathrm{mg} / \mathrm{mL})$, at $4^{\circ} \mathrm{C}, 15,000 \boldsymbol{g}$ for $40 \mathrm{~min}$. Aliquots of the lysates containing $50 \mu \mathrm{g}$ of protein were denatured in Laemmli sample buffer $(6 \%$ SDS, 30\% glycerol, $0.02 \%$ bromophenol blue, $200 \mathrm{~mm}$ Tris- $\mathrm{HCl}$ (pH 6.8) and $250 \mathrm{~mm}$ mercaptoethanol), at $95^{\circ} \mathrm{C}$ for $5 \mathrm{~min}$. Samples were blotted onto nitrocellulose membrane. Nonspecific binding was prevented by immersing the membranes in blocking buffer (10\% BSA in Tris-buffered saline-Tween 20, TBS-T) for $90 \mathrm{~min}$ at room temperature. The membranes were then exposed 
overnight to the primary antibodies: rabbit anti-IRS-1 (1:5000, Cell Signaling \# 2390); rabbit anti-phospho IRS-1 tyr1222 (1:1500, Cell Signaling \# 3066), rabbit anti $\beta$-actin (1:1000, Cell Signaling \# 8457), rabbit anti-AKT (1:10000, Cell Signaling \# 4691); rabbit anti-phospho AKT S473 (1:1500, Cell signaling \# 9271), rabbit antiJNK (1:5000, Cell Signaling \# 9252), rabbit anti-phospho JNK (1:1000, Cell Signaling \# 9251), goat anti-PTP1B $(0,15 \mu \mathrm{g} / \mathrm{mL}, \mathrm{AF} 3954$ - R\&D Systems $)$ and rabbit antiTCPTP (1:3000, AB180714-Abcam). The blots were rinsed in TBS-T and then incubated with horseradish peroxidase (HRP)-conjugated anti-rabbit antibody (1:5000, Cell Signaling \# 7074) or donkey anti-goat IgG-B (1:10000, Santa Cruz SC2042) for $1 \mathrm{~h}$ at room temperature. Antibodyantigen complexes were visualized by detecting enhanced chemiluminescence by ECL detection system (Amersham Biosciences) in digital images using Quantity One 4.5.0 software (Bio-Rad). To normalize pIRS, pAKT and pJNK levels, total IRS1, total AKT and total JNK were used, respectively. B-actin was used to normalize PTP1B and TCPTP. Data are expressed as percentage of the calibrator group, and, similarly to the relative quantification of mRNA, to get the relative quantification, appropriate calibrator groups were used as control to compare: (1) the effect of treatment (vehicle or insulin) on protein content in each group (sham, ADX, $\mathrm{ADX}+\mathrm{B})$; (2) the effect of glucocorticoid sufficiency or not (sham, ADX, ADX $+\mathrm{B}$ ) on protein content in vehicle- and insulin-treated animals. To attain the first and second analysis, the respective vehicle group and sham-vehicle or sham-insulin group were used as calibrator, respectively.

\section{Experimental protocols}

\section{Effects of ADX and B treatment on the mRNA} expression of insulin receptor in the ARC, PVN, DMH and $\mathrm{VMH}$ and corticosterone plasma levels

Animals were subjected to either sham or ADX surgery, and half of the ADX animals received B in their drinking fluid. Animals were individually housed in plastic cages. Seven days after surgery, food was withdrawn at 16:00 h and, at $17: 30 \mathrm{~h}$, a first set of sham, $\mathrm{ADX}$ and $\mathrm{ADX}+\mathrm{B}$ animals ( $n=7-9$ per group) were decapitated for trunk blood and brain tissue collection, corticosterone plasma levels were determined by radioimmunoassay and InsR mRNA was determined by real-time PCR.

\section{Effects of the central injection of insulin on food intake in sham, $A D X$ and $A D X+B$ animals}

Immediately after icv surgery, animals ( $n=5-7$ per group) were subjected to either sham or ADX surgery, and half of the ADX animals received $\mathrm{B}$ in their drinking fluid. Animals were individually housed in hanging cages. Seven days after surgery, food was withdrawn at 16:00h, and $90 \mathrm{~min}$ later they received an icv injection of vehicle $(0.9 \% \mathrm{NaCl} / 5 \mu \mathrm{L})$ or insulin $(12 \mu \mathrm{M} / 5 \mu \mathrm{L})$. Fifteen minutes after the injections, food was reintroduced, and food consumption was determined after 1, 2, 4, 14 and $22 \mathrm{~h}$ of food access.

\section{Effects of the central injection of insulin on the hypothalamic levels of insulin signaling-related molecules in sham, ADX and ADX + B animals}

Immediately after icv surgery, animals ( $n=5-10$ per group) were subjected to either sham or ADX surgery, and half of the ADX animals received $\mathrm{B}$ in their drinking fluid. Animals were individually housed in hanging cages. Seven days after surgery, food was withdrawn at 16:00 h, and $90 \mathrm{~min}$ later, they received an icv injection of vehicle $(0.9 \% \mathrm{NaCl} / 5 \mu \mathrm{L})$ or insulin $(12 \mu \mathrm{M} / 5 \mu \mathrm{L})$. Fifteen minutes after the injections, sham, $\mathrm{ADX}$ and $\mathrm{ADX}+\mathrm{B}$ animals were decapitated for brain tissue collection, and the levels of hypothalamic insulin signaling molecules were determined by Western blotting analyses.

\section{Effects of the central injection of insulin on the mRNA expression of hypothalamic neuropeptides in sham, $A D X$ and $A D X+B$ animals}

Immediately after icv surgery, animals ( $n=5-10$ per group) were subjected to either sham or ADX surgery, and half of the ADX animals received $B$ in their drinking fluid. Animals were individually housed in hanging cages. Seven days after surgery, food was withdrawn at 14:00 h, and $90 \mathrm{~min}$ later, they received an icv injection of vehicle $(0.9 \% \mathrm{NaCl} / 5 \mu \mathrm{L})$ or insulin $(12 \mu \mathrm{M} / 5 \mu \mathrm{L})$. Sham, ADX and $\mathrm{ADX}+\mathrm{B}$ animals were decapitated $120 \mathrm{~min}$ after the injections for brain tissue collection, and mRNA expression of hypothalamic neuropeptides was determined by real-time PCR.

\section{Statistical analysis}

The data are presented as means \pm s.E.M. The normal distribution and homogeneity of the data were tested. One-way ANOVA (InsR mRNA results, mRNA results and protein levels, in the comparison among sham, ADX and $\mathrm{ADB}+\mathrm{B}$ groups in each treatment) and two-way ANOVA (food intake), followed by Newmann-Keuls (or Kruskal-Wallis test) post hoc test and Student $t$-test or Mann-Whitney test (mRNA results and protein levels, in the comparison between vehicle and insulin treatments 
in each experimental group) were used when appropriate. Pearson or Spearman correlation tests were used for the analysis of correlation between corticosterone plasma levels and InsR mRNA expression. Differences were considered significant at $P<0.05$.

\section{Results}

ADX decreases insulin receptor mRNA expression and increases the levels of insulin counter-regulatory proteins in the hypothalamus

ADX decreased $(P<0.05)$ InsR mRNA expression in the ARC (Fig. 1A), PVN (Fig. 1B), DMH (Fig. 1C) and VMH (Fig. 1D), compared to sham group. Corticosterone treatment reversed this response in the PVN and $\mathrm{VMH}$ and it partially reversed it $(P<0.05)$ in the ARC and DMH. Sham group showed higher $(P<0.05)$ corticosterone concentrations than $\mathrm{ADX}+\mathrm{B}$ group $(10.1 \pm 0.5 \mu \mathrm{g} / \mathrm{dL}$ vs $7.0 \pm 0.7 \mu \mathrm{g} / \mathrm{dL}$ ), and both groups showed higher $(P<0.05)$ values than ADX group $(0.45 \pm 0.02 \mu \mathrm{g} / \mathrm{dL})$. A positive and significant correlation was observed between plasma corticosterone levels and insulin receptor mRNA expression in the ARC (Fig. 2A, $P=0.0036, r=0.55$ ), PVN (Fig. $2 \mathrm{~B}, P<0.0001, r=0.85$ ), DMH (Fig. $2 \mathrm{C}, P<0.0001$, $r=0.73$ ) and VMH (Fig. 2D, $P=0.02, r=0.45$ ). Compared to sham animals, ADX increased $(P<0.05)$ hypothalamic levels of PTP1B (Fig. 3A), TCPTP (Fig. 3B) and pJNK/JNK (Fig. 3C), and corticosterone treatment partially reversed the effect on pJNK and normalized the levels of PTP1B and TCPTP.

\section{Adrenalectomy abolishes insulin-induced hypophagia}

ADX/vehicle animals showed decreased $(P<0.05)$ food intake, when compared to sham/vehicle and this response was reversed by B treatment after 1, 2, 4, 14 and $22 \mathrm{~h}$. Central injection of insulin decreased $(P<0.05)$ food intake in sham rats after $1 \mathrm{~h}$, with no effects in ADX rats. However, insulin did not change food consumption at the other times evaluated. Though a nonsignificant trend was observed in the $\mathrm{ADX}+\mathrm{B}$ group, corticosterone treatment did not rescue the hypophagic effect of insulin (Fig. 4).

\section{Adrenalectomy reduces insulin signaling in the hypothalamus}

The comparison with vehicle injection showed that central insulin enhanced $(P<0.05)$ hypothalamic pAKT/AKT protein content only in the sham group, with no effects in ADX and ADX $+B$ animals (Fig. 5B), but insulin treatment did not alter hypothalamic pIRS1/IRS1 levels in the three experimental groups (Fig. 5A). Central insulin injection did not alter protein levels of pERK1/2/ERK1/2 in sham, $\mathrm{ADX}$ or $\mathrm{ADX}+\mathrm{B}$ groups (Fig. $5 \mathrm{C}$ ), compared to vehicle injection. After vehicle microinjection, there was no difference in the relative amount of hypothalamic pIRS1/IRS and pAKT/AKT among sham, ADX and ADX + B groups (Fig. 6A and $\mathrm{C}$ ). In insulin-treated animals, there was a reduction $(P<0.05)$ in the hypothalamic levels of pIRS1/IRS and pAKT/AKT of ADX and ADX + B groups, compared with sham animals (Fig. 6B and D). In vehicleor insulin-treated animals, hypothalamic levels of
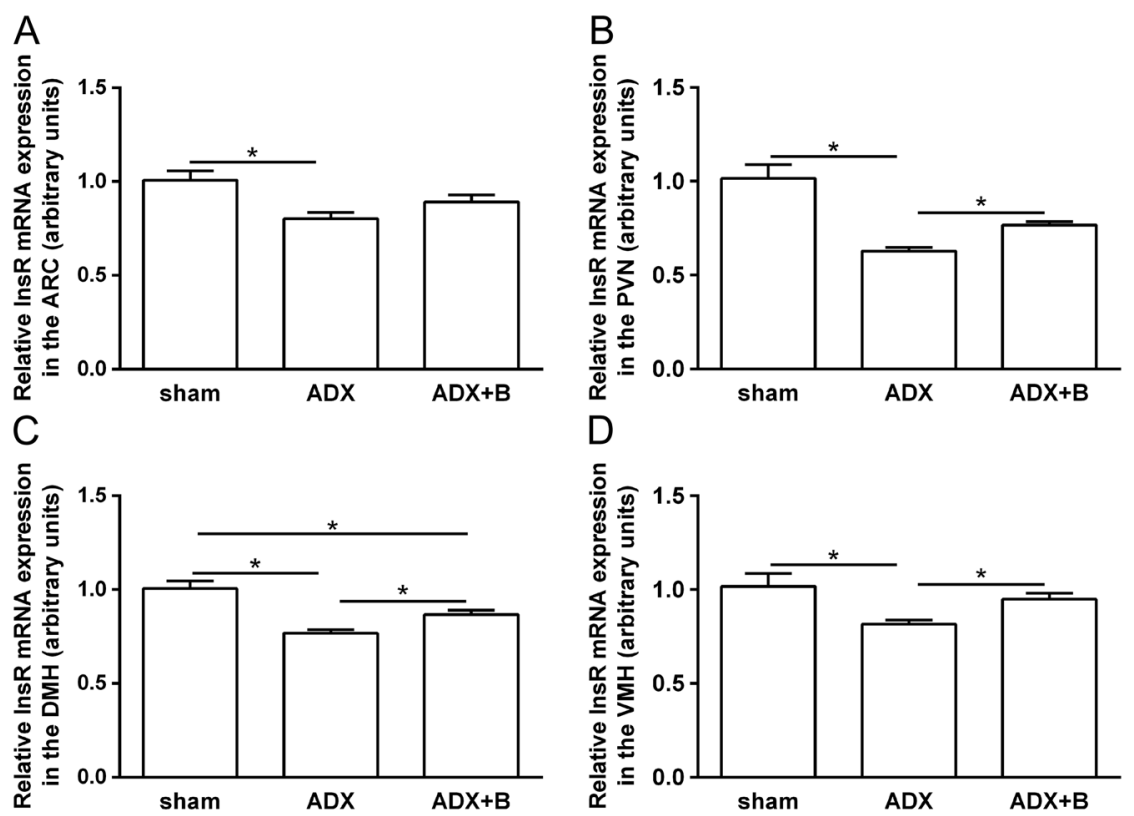

Figure 1

Relative expression of insulin receptor mRNA in the arcuate (ARC) (A), paraventricular (PVN) (B), dorsomedial (DMH) (C) and ventromedial (VMH) (D) nuclei of the hypothalamus of sham, ADX, and $A D X+B$ animals ( $n=7-10$ rats/group). Data are shown as means \pm S.E.M. $* P<0.05$. 
A

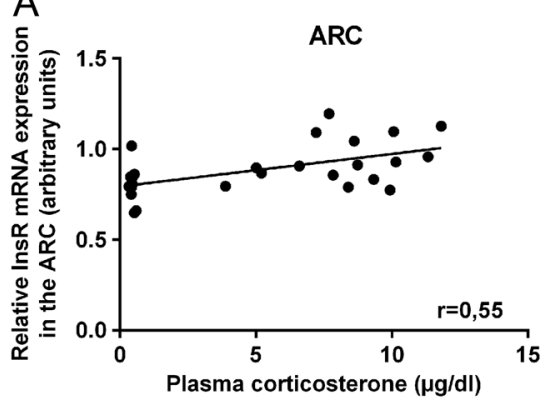

C

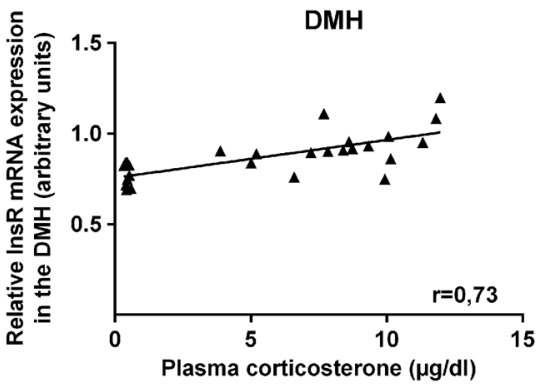

B

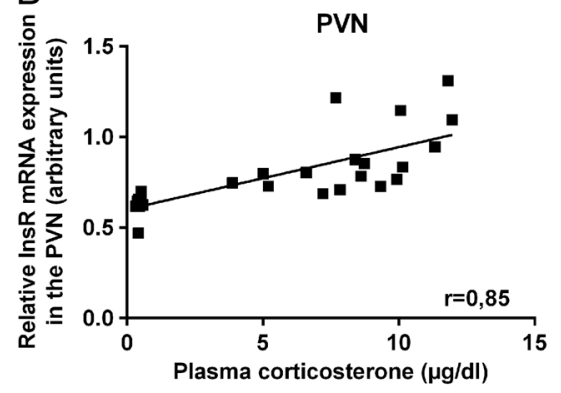

D

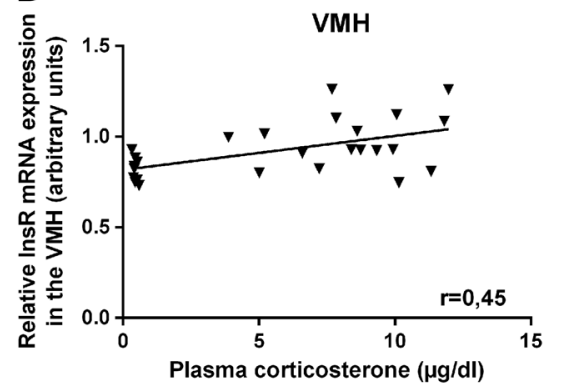

Figure 2

Correlation between corticosterone plasma levels and relative expression of insulin receptor mRNA in the arcuate (ARC) (A), paraventricular (PVN) (B), dorsomedial (DMH) (C) and ventromedial (VMH) (D) nuclei of the hypothalamus of sham, ADX and ADX $+B$ animals ( $n=7-10$ rats/group). Pearson or Spearman correlation analyses were ARC $(P=0.0036, r=0.55)$, PVN $(P<0.0001, r=0.85)$, $\mathrm{DMH}(P<0.0001, r=0.73)$ and $\mathrm{VMH}(P=0.02$, $r=0.45)$.
pERK1/2/ERK1/2 were not different among sham, ADX and $\mathrm{ADX}+\mathrm{B}$ groups (Fig. $6 \mathrm{E}$ and $\mathrm{F}$ ).

\section{Adrenalectomy impairs insulin-induced changes in the expression of hypothalamic neuropeptides}

Central insulin injection was able to enhance $(P<0.05)$ Cart mRNA expression (Fig. 7B) and to reduce Npy mRNA expression (Fig. 7C) in the ARC only in the sham group, with no effects in $\mathrm{ADX}$ and $\mathrm{ADX}+\mathrm{B}$ animals, but insulin treatment did not change hypothalamic mRNA expression of other neuropeptides in the three experimental groups (Fig. 7). In vehicle-treated animals, ADX reduced $(P<0.05)$ Pomc, Cart, Npy and Agrp mRNA expression in the ARC, but it increased $(P<0.05)$ Crf mRNA expression in the PVN, compared to sham group, while corticosterone replacement was able to reverse $(P<0.05)$ these effects (Fig. 8A, C, E, G and I). In insulin-treated animals, Cart mRNA expression in the ARC was reduced $(P<0.05)$ in $\mathrm{ADX}$ and $\mathrm{ADX}+\mathrm{B}$ groups, compared to sham group (Fig. 8D). In insulin-treated animals, expression of $\mathrm{Crf}$ mRNA in the PVN was also augmented in the ADX group, with no changes in Pomc, Npy and Agrp mRNA expression (Fig. 8B, F and H).

\section{Discussion}

The present study addressed the mechanisms by which glucocorticoids are involved in the central treatment of insulin on food intake. First, we observed that the ADX group had increased levels of insulin signaling
A
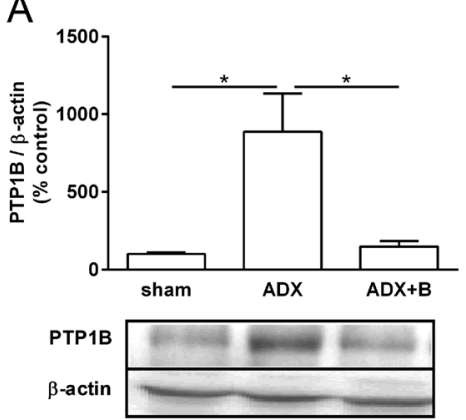

B

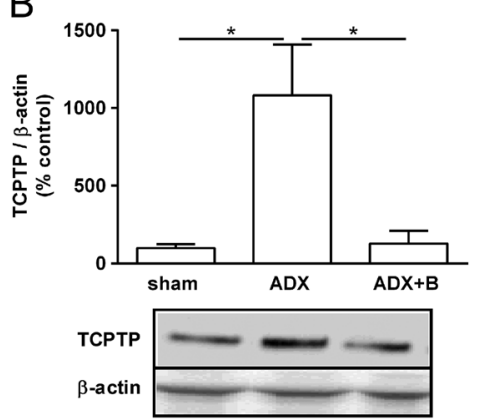

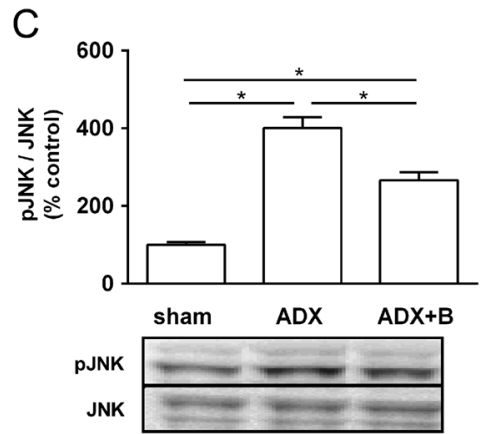

Figure 3

Percentage of protein tyrosine phosphatase-1B (PTP1B) (A), T cell protein tyrosine phosphatase (TCPTP) (B) and Phospho-c-Jun N-terminal Kinase (pJNK) (C) levels in the mediobasal hypothalamus of sham, ADX and ADX $+B$ animals ( $n=5-8$ rats/group). Data are shown as means \pm S.E.M. $* P<0.05$. 


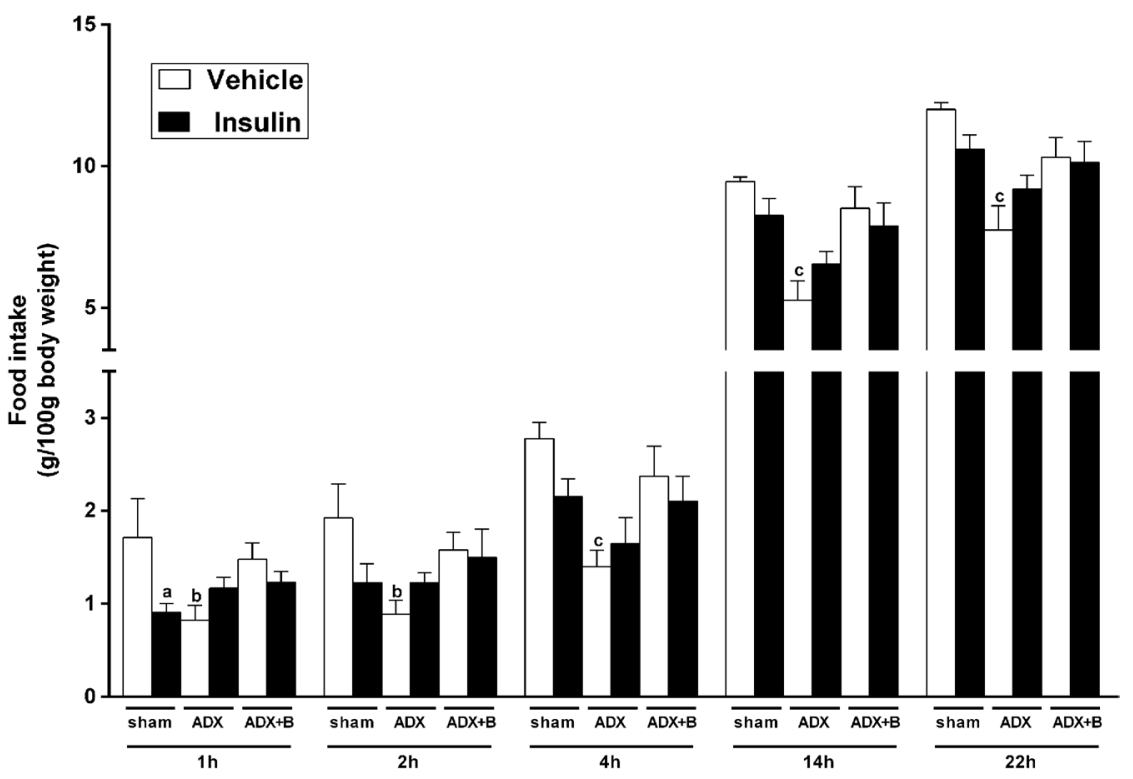

\section{Figure 4}

Food intake (g/100 g) after 1, 2, 4, 14 and $22 \mathrm{~h}$ of food access ( $n=5-7$ rats/group) of sham, ADX and $A D X+B$ animals treated with central vehicle $(0.9$ $\mathrm{NaCl} / 5 \mu \mathrm{L})$ or insulin $(12 \mu \mathrm{M} / 5 \mu \mathrm{L})$. Data are shown as means \pm S.E.M. $a P<0.05$ vs insulin, $b P<0.05$ vs respective $A D X$ group, $c P<0.05$ vs respective $A D X$ and $A D X+B$ groups. counter-regulators pJNK, PTP1B and TCPTP, and reduced expression of InsR in the hypothalamus. Moreover, hypothalamic expression of InsR mRNA was shown to be positively correlated with plasma corticosterone levels, and hypophagia induced by central insulin injection was absent after ADX. Finally, ADX abolished the insulininduced pAKT and Cart mRNA expression and the decrease of Npy mRNA expression in the hypothalamus.

In vehicle animals, ADX-induced increase in PVN Crf mRNA and reductions in Pomc, Cart, Npy and Agrp mRNA in the ARC is well established in the literature, since $\mathrm{ADX}$ is known to reduce the expression of orexigenic neuropeptides Npy and Agrp (Savontaus et al. 2002, Uchoa et al. 2012) and to increase the expression of anorexigenic neuropeptide Crf (Uchoa et al. 2010). In addition, the reduction of Pomc and Cart induced by ADX had already been reported by different works, probably to due lower levels of plasma insulin and leptin in these animals
(Savontaus et al. 2002, Germano et al. 2007, Uchoa et al. 2012). As observed, corticosterone treatment was not effective to restore all the effects induced by ADX, and this phenomenon may be ascribed to the experimental design, since rats eat and drink mostly during the night. As the experiments were conducted at the end of the day, it is likely that circulating plasma levels of corticosterone of $\mathrm{ADX}+\mathrm{B}$ animals were not as high as sham group because they stayed the last hours without drinking fluid, although B was available throughout the day. This hypothesis is confirmed by the plasma levels of corticosterone, where sham group had upper corticosterone concentrations than $\mathrm{ADX}+\mathrm{B}$ group, and both groups showed higher values than ADX group. In addition, it cannot be ruled out the possibility that other hormones of adrenal glands, as mineralocorticoids, could also participate on these responses. In fact, replacement with mineralocorticoid to $\mathrm{ADX}$ rats, in addition to glucocorticoid replacement
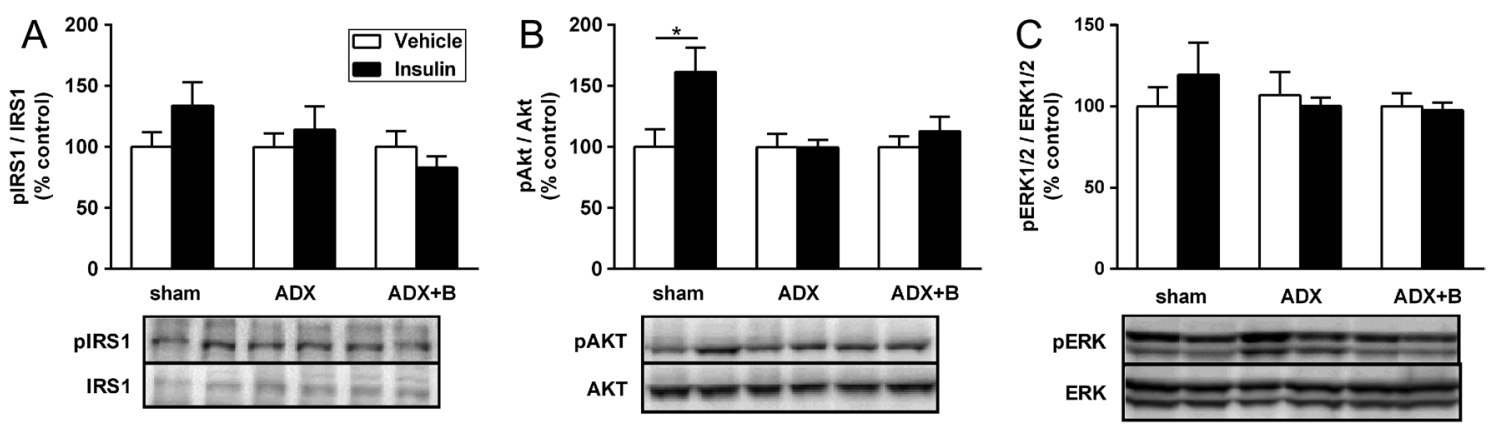

\section{Figure 5}

Levels of phospho-insulin receptor substrate (IRS) 1 (A), phospho-protein kinase B (AKT) (B) and phospho-extracellular-signal-regulated kinase (ERK1/2) (C) in the mediobasal hypothalamus of sham, $\mathrm{ADX}$ and $\mathrm{ADX}+\mathrm{B}$ animals $15 \mathrm{~min}$ after the icv injection of vehicle $(0.9 \% \mathrm{NaCl} / 5 \mu \mathrm{L})$ or insulin $(12 \mu \mathrm{M} / 5 \mu \mathrm{L})$ ( $n=5-8$ rats/group). Vehicle in each group was used as calibrator. Data are shown as means \pm S.E.M. $* P<0.05$. 
A
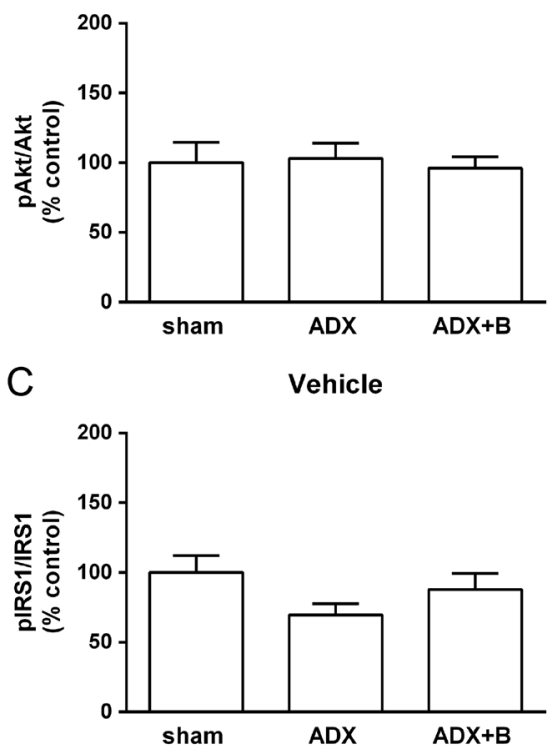

E

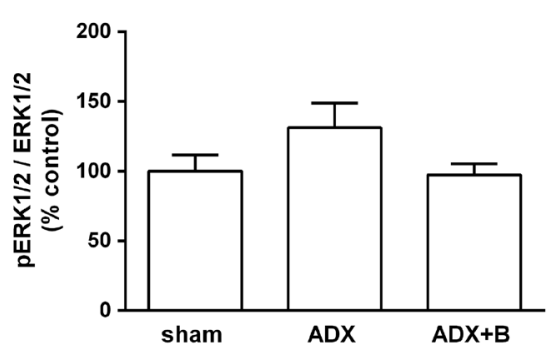

B
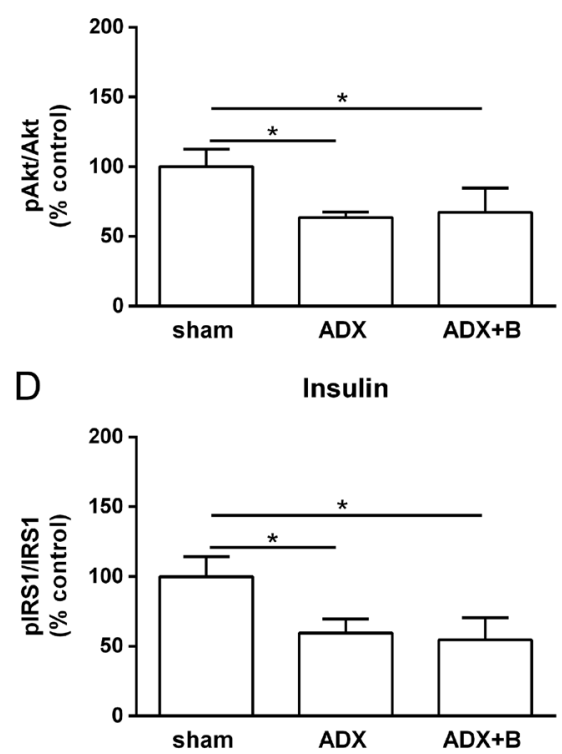

F

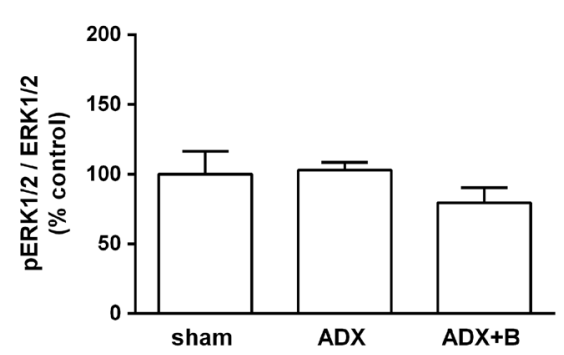

\section{Figure 6}

Levels of phospho-insulin receptor substrate (IRS) 1 (A), phospho-protein kinase B (AKT) (B) and phospho-extracellular-signal-regulated kinase (ERK1/2) (C) in the mediobasal hypothalamus of sham, $A D X$ and $A D X+B$ animals 15 min after the icv injection of vehicle $(0.9 \% \mathrm{NaCl} / 5 \mu \mathrm{L})(\mathrm{A}, \mathrm{C}$ and E) or insulin $(12 \mu \mathrm{M} / 5 \mu \mathrm{L})(n=5-11$ rats/group) (B, $\mathrm{D}$ and F). ( $n=5-8$ rats/group). Respective sham group was used as calibrator in each treatment. Data are shown as means \pm S.E.M. $* P<0.05$. (aldosterone+cortiscosterone), was effective in boosting food intake and body weight gain beyond that of only corticosterone replacement (Devenport et al. 1983, 1985). In addition, aldosterone replacement to ADX animals restored daily caloric intake, specially lipid intake, and body fat deposition, and this preferential role in fat balance is most clearly seen during the later hours of the feeding cycle (Devenport \& Devenport 1982, Tempel \& Leibowitz 1989). Altogether, these data demonstrated that, besides corticosterone, aldosterone is another adrenal hormone in controlling body weight gain and food intake in rats.

Insulin-induced reduction in food intake and increase in the phosphorylation of AKT in the hypothalamus observed in sham animals is supported by previous work of Niswender et al. (2003), who reported that hypophagic effect of central treatment of insulin is mediated by PI3K pathway, which recruits IRS/AKT cascade in the hypothalamus. Although no significant trend in insulin treatment to increase IRS1 phosphorylation, sham animals showed higher levels of pIRS1 levels than ADX and ADX $+B$ animals after insulin treatment, suggesting that IRS1 may contribute to hypophagia induced by insulin in sham group. However, as IRS2 has been suggested to have pivotal role in insulin effects on energy homeostasis, it is also reasonable to suggest that IRS2 may also be involved in insulin-induced activation of IRS/PI3K/AKT signaling pathway (Pardini et al. 2006). In addition, insulininduced hypophagia in sham group was associated with enhancement of Cart mRNA expression in the ARC as well as reduction of Npy mRNA in this nucleus. Indeed, insulin is known to decrease Npy expression in the ARC and its release in the PVN (Schwartz et al. 1991, 1992, Wang \& Leibowitz 1997), as well as to increase Cart expression in the hypothalamus (Honda et al. 2007). Moreover, diabetic animals, with insulin deficiency, also show reduced Cart expression in the ARC (Li et al. 2002), reinforcing the present findings. Additionally, studies from the literature reported that insulin was also able to increase Pomc and Crf expression in the hypothalamus and reduce Agrp expression; thus, the lack of changes in the expression of Pomc, Agrp and Crf mRNA after central treatment with insulin may be due to experimental differences (Benoit et al. 2002, Chan et al. 2005). 

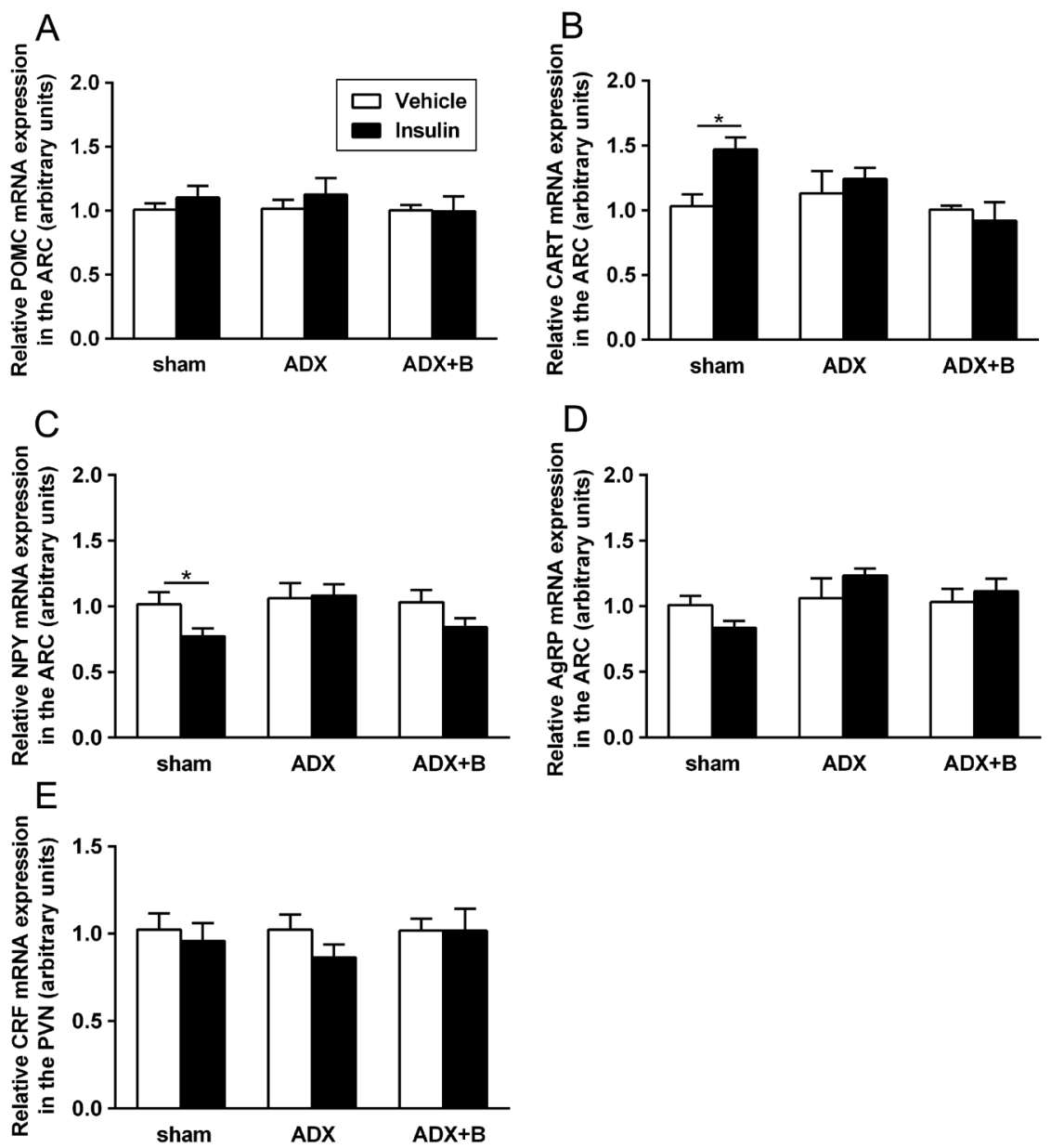

Figure 7

Relative mRNA expression of proopiomelanocortin (Pomc) (A), cocaine and amphetamine-regulated transcript (Cart) (B), neuropeptide $\mathrm{Y}(\mathrm{Npy})(\mathrm{C})$, agouti-related protein (Agrp) (D) in the arcuate nucleus of the hypothalamus (ARC) and corticotrophin-releasing factor $(\mathrm{Crf})(\mathrm{E})$ in the paraventricular nucleus of the hypothalamus (PVN) of sham, ADX and $A D X+B$ animals 120 min after the icv injection of vehicle $(0.9 \% \mathrm{NaCl} / 5 \mu \mathrm{L})$ or insulin $(12 \mu \mathrm{M} / 5 \mu \mathrm{L})$ ( $n=5-11$ rats/group). Vehicle in each group was used as calibrator. Data are shown as mean \pm S.E.M. ${ }^{*} P<0.05$.
It is known that insulin effects, both in the periphery and CNS, have been classically ascribed to insulin binding to its receptor in the membrane, a tyrosine kinase receptor which autophosphorylate itself in the internal surface of the cell upon insulin binding, and thereby activates its intrinsic tyrosine kinase activity, resulting in phosphorylation of IRS proteins on tyrosine residues. This phosphorylation can activate PI3K and/or MAPK pathways (Niswender \& Schwartz 2003, Plum et al. 2005, Vogt \& Brüning 2013). Activated PI3K rapidly mediates the phosphorylation of PI 4,5-biphosphate to PI 3,4,5-triphosphate, a key signaling intermediate that recruits and activates downstream molecules, including phosphoinositide-dependent kinase 1 , which in turn phosphorylates and thus activates the kinase AKT to elicit downstream signaling events, as activation and/or repression of target genes encoding hypothalamic neuropeptides involved in the regulation of food intake (Niswender \& Schwartz 2003, Plum et al. 2005, Vogt \& Brüning 2013). In this context, Yang et al. (2010) demonstrated, by means of eletrophysiological approaches, that insulin-induced reduction in the activity of Npy neurons in the ARC is mediated by IRS/PI3K/AKT pathway, but not by MAPK signaling, reinforcing that insulin-mediated activation of the MAPK/ERK pathway in the control of food intake and energy homeostasis is not well established. On the other hand, Mayer and Belsham (2009) have shown, using hypothalamic neuronal cell line, that insulin regulates Npy and Agrp expression through MAPK pathway but not by IRS/PI3K/AKT signaling. Accordingly, it can be suggested that insulin is likely to reduce food intake by recruiting hypothalamic IRS/PI3K/AKT pathway, and thus modulates hypothalamic expression of neuropeptides involved in the control of food intake, stimulating the anorexigenic neuropeptide Cart and reducing the orexigenic neuropeptide Npy.

Impaired insulin signaling in the hypothalamus, as observed by the absence of phosphorylation of AKT and changes in the expression of Cart and Npy mRNA in response to insulin treatment in ADX animals, is likely to underlie the lack of anorexigenic effect of insulin after ADX. Indeed, one possible mechanism for this impairment of insulin effects after ADX may be ascribed to lower 

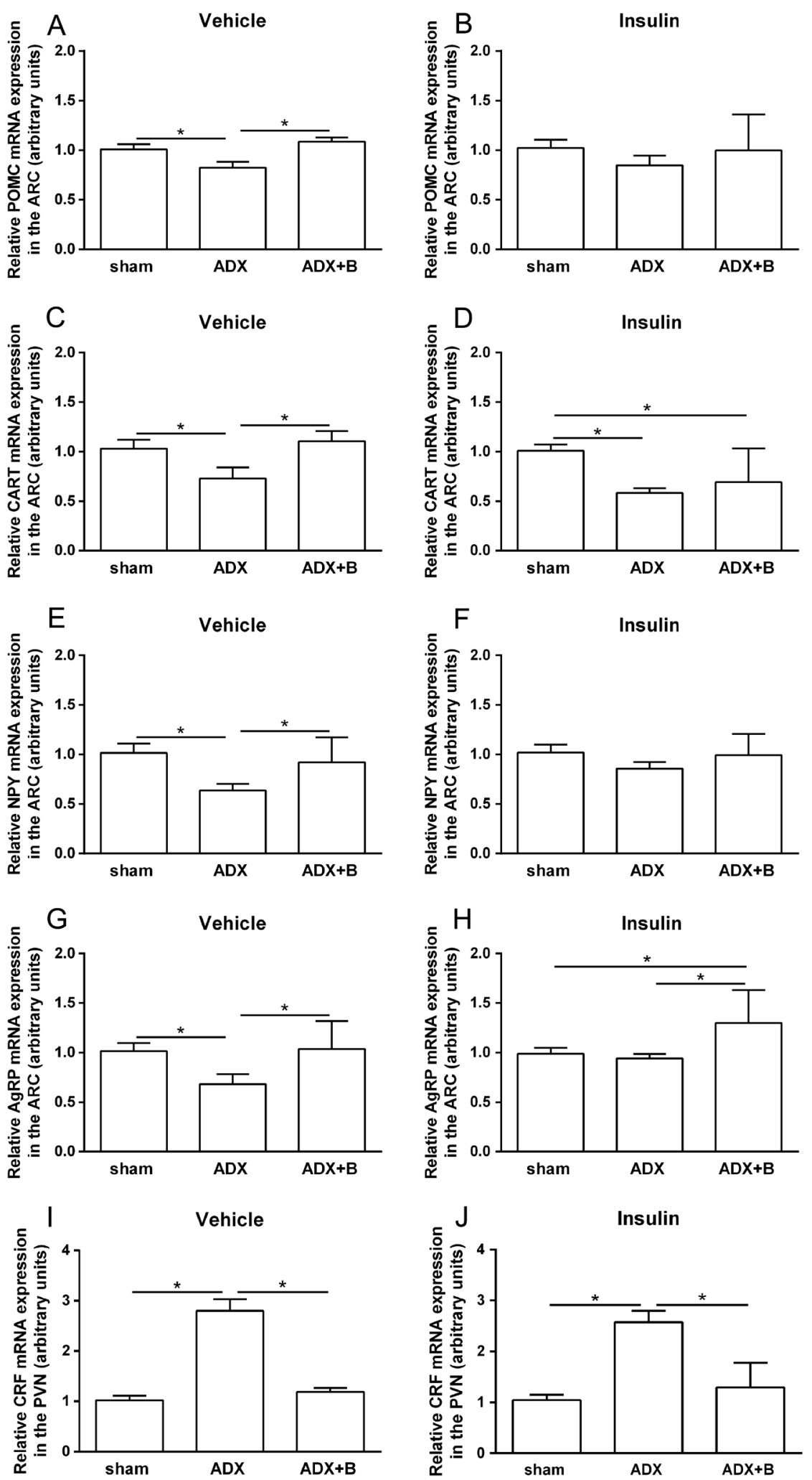

Relative mRNA expression of

proopiomelanocortin (Pomc) (A), cocaine and amphetamine-regulated transcript (Cart) (B), neuropeptide $Y(N p y)(C)$, agouti-related protein (Agrp) (D) in the arcuate nucleus of the hypothalamus (ARC) and corticotrophin-releasing factor ( $\mathrm{Cr} f$ ) (E) in the paraventricular nucleus of the hypothalamus (PVN) of sham, ADX and $A D X+B$ animals 120 min after the icv injection of vehicle $(0.9 \% \mathrm{NaCl} / 5 \mu \mathrm{L})(\mathrm{A}, \mathrm{C}, \mathrm{E}, \mathrm{G}$ and $\mathrm{I})$ or insulin $(12 \mu \mathrm{M} / 5 \mu \mathrm{L})(n=5-11$ rats/group) (B, D, F, H and J). Respective sham group was used as calibrator in each treatment. Data are shown as mean \pm S.E.M. ${ }^{*} P<0.05$.

expression of InsR in the hypothalamus in ADX animals, which might compromise the IRS/PI3K/AKT pathway. In this context, the reduction of InsR mRNA expression in different nuclei of hypothalamus is supported by in vitro experiments demonstrating that glucocorticoids increased InsR expression in different cell lines, as well by in vivo data 
that showed that the glucocorticoid prednisone increased the number of InsR on circulating monocytes in normal subjects (Beck-Nielsen et al. 1980, Iwama et al. 1987, McDonald et al. 1987, Mamula et al. 1990, Desbuquois et al. 1993). Accordingly, the positive correlation between plasma corticosterone levels and InsR mRNA expression in the hypothalamus indicates that glucocorticoids seem to stimulate the expression of InsR, not only in vitro, but also in in vivo, as suggested in the current study. In addition, glucocorticoids were shown to mediate phosphorylation of retinal AKT induced by stress (Forkwa et al. 2014). Thus, it is likely that circulating glucocorticoids are required for hypothalamic expression of InsR and consequently for insulin-induced activation of AKT signaling pathway and changes in neuropeptides expression in the hypothalamus, as well as for the anorexigenic actions of insulin.

On the other hand, Chavez et al. (1997) demonstrated that ADX enhanced the sensitivity to central insulin effects on food intake, since continuous infusion of insulin in the third ventricle was able to reduce food intake only in ADX animals, without effects in the adrenal-intact group. The difference between these data and the present study might be due to methodological and protocol differences, such as injection site and duration of the treatment. In addition to insulin, the interaction of ADX with other peripheral hormones, as leptin and CCK, was described in previous studies. Concerning leptin, the interaction with ADX remains controversial, since several studies have pointed different results. Pioneer studies in this field have pointed that the absence of glucocorticoids increases the brain's sensitivity to leptin to decrease food intake and body weight (Zakrzewska et al. 1997, Madiehe et al. 2001), while another study of Arvaniti et al. (1998) showed that the ability of leptin to inhibit body gains in energy and fat is not dependent on the presence of corticosterone. On the other hand, another study reports that leptin has a more pronounced effect on weight loss in ADX rats with CORT replacement than it does on ADX rats without CORT replacement (Gemmill et al. 2003). Concerning CCK, similarly to the interaction with insulin in the present manuscript, ADX was shown to abolish CCK-induced hypophagia, probably because CCK could not further reduce food intake more than ADX has already reduced, to preserve the energy homeostasis of the organism (Uchoa et al. 2009a). In addition, CCK-induced activation of NTS neurons, but, interestingly, it did not further reduce food intake in the ADX group, demonstrating that the unchanged food intake in ADX animals following CCK administration was dissociated from the increased Fos expression in NTS neurons (Raboin et al. 2006, Uchoa et al. 2009a). Overall, these responses occur in an attempt to preserve energy homeostasis in the presence of glucocorticoid deficiency.

It is known that PTP1B and TCPTP are PTPs that attenuate insulin signaling by dephosphorylating tyrosine phosphorylated in insulin receptor or IRS (Zhang et al. 2015), while JNK phosphorylates serine residues of IRS-1, blocking the interaction between the IRS- 1 domain and the insulin receptor (Aguirre et al. 2000, Belgardt et al. 2010). Thus, higher levels of the counter-regulators of insulin signaling, pJNK, PTP1B and TCPTP observed after ADX may also induce the impaired actions of IRS/PI3K/AKT pathway in ADX animals. Accordingly, glucocorticoids have been demonstrated to reduce the phosphorylation of JNK in different tissues, since JNK has pro-inflammatory effects, while glucocorticoids are classically known to exert anti-inflammatory actions (Adcock \& Caramori 2001, Motta et al. 2015). However, this is the first work to demonstrate that ADX increase the levels of PTP1B and TCPTP. Though it is well established in the literature that glucocorticoids counter-regulate insulin actions in energy homeostasis in peripheral tissues (Olefsky 1975, Haluzik et al. 2002, Long et al. 2003), the present study demonstrates for the first time that glucocorticoid withdrawal induced by ADX affects insulin signaling molecules in the hypothalamus. Thus, we postulate that the mechanisms by which adrenalectomy abolishes hypothalamic responses to insulin treatment involve the reduction in the expression of InsR and increases in the expression of counter-regulators of insulin signaling pJNK, PTP1B and TCPTP in the hypothalamus. These alterations lead to an impaired AKT signaling pathway as well as changes in neuropeptides expression (Npy and Cart) in the hypothalamus, then abolishing hypophagia induced by insulin (Fig. 9).

Finally, it is important to mention that insulin increased Cart mRNA expression and reduced Npy mRNA expression in the ARC, and that ADX abolished these effects; therefore, this nucleus could be considered as a key area for the effects of insulin on food intake regulation. However, changes in the medial basal hypothalamus were also detected after ADX, as enhancement of pJNK, PTP1B and TCPTP as well as reductions in the expression of insulin receptor in other nuclei than ARC, suggesting that these other regions are also important to explain the results. Food intake is regulated by a complex circuitry comprising different hypothalamic nuclei as other extra-hypothalamic area (Morton et al. 2006); therefore, signaling pathways from other sites than ARC, such as PVN and NTS could be also affected by ADX. To ascertain 


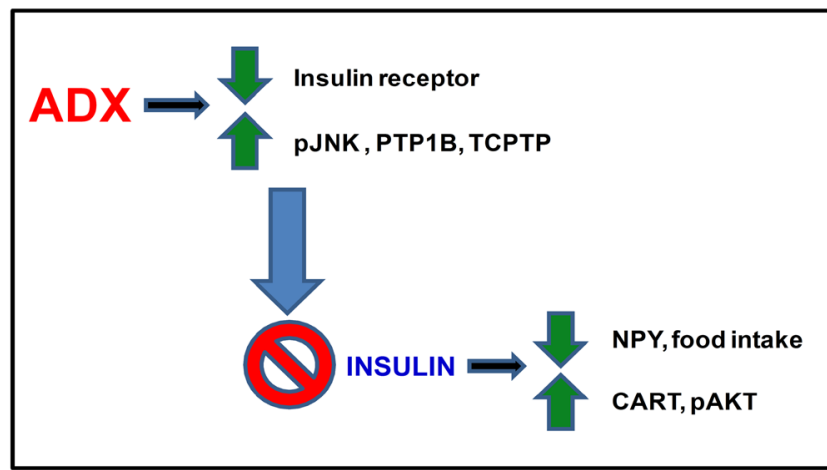

\section{Figure 9}

Schematic diagram demonstrating that adrenalectomy (ADX) reduces the expression of insulin receptor and increases the levels of the counterregulators of insulin signaling phosphorylated c-Jun $\mathrm{N}$-terminal kinase (pJNK), protein tyrosine phosphatase-1B (PTP1B) and T cell protein tyrosine phosphatase (TCPTP), which are likely to yield impairment of insulininduced phosphorylation of protein kinase B (pAKT) in the hypothalamus, insulin-induced changes mRNA expression of cocaine and amphetamineregulated transcript (Cart) and neuropeptide $Y(N p y)$ in the arcuate nucleus of the hypothalamus and hypophagia induced by insulin. A full colour version of this figure is available at https://doi.org/10.1530/JOE-19-0217.

this complex neuron network, specific or conditioned gene manipulation would help to better dissect the most prominent neuronal pathway involved in the impaired sensitivity to insulin after ADX in future studies.

In summary, the most remarkable outcome of the present study was that central administration of insulin requires the presence of intact adrenal to reduce food intake, in addition to the mechanisms underlying this interaction between glucocorticoid and insulin action in the hypothalamus. In this context, it is noteworthy that reduced expression of InsR and enhanced levels of its counter-regulator molecules, JNK, PTP1B and TCPTP in the hypothalamus may underlie the mechanisms by which ADX impairs insulin-induced recruitment of IRS1/AKT signaling pathway. These effects may be important to counteract the effects of glucocorticoid deficiency on food intake to prevent a more profound hypophagia and to preserve the homeostasis of the animals.

\section{Declaration of interest}

The authors declare that there is no conflict of interest that could be perceived as prejudicing the impartiality of the research reported.

\section{Funding}

This work was supported by Fundacao de Amparo a Pesquisa do Estado de Sao Paulo (FAPESP 13/09799-1), Conselho Nacional de Desenvolvimento Cientifico e Tecnologico (CNPq 151285/2013-6) and Coordenação de Aperfeiçoamento de Pessoal de Nível Superior (CAPES), Brazil.

\section{Statement of ethics}

All experimental procedures were approved by the Ethical Committee for Animal Use of the School of Medicine of Ribeirao Preto, University of Sao Paulo, Brazil (protocol number 092/2011).

\section{Acknowledgments}

The authors are grateful to Maria Valci dos Santos and Milene Mantovani Lopes for their excellent technical assistance.

\section{References}

Adcock IM \& Caramori G 2001 Cross-talk between pro-inflammatory transcription factors and glucocorticoids. Immunology and Cell Biology 79 376-384. (https://doi.org/10.1046/j.1440-1711.2001.01025.x)

Aguirre V, Uchida T, Yenush L, Davis R \& White MF 2000 The c-Jun $\mathrm{NH}(2)$-terminal kinase promotes insulin resistance during association with insulin receptor substrate-1 and phosphorylation of Ser(307). Journal of Biological Chemistry 275 9047-9054. (https://doi. org/10.1074/jbc.275.12.9047)

Arvaniti K, Deshaies Y \& Richard D 1998 Effect of leptin on energy balance does not require the presence of intact adrenals. American Journal of Physiology 275 R105-R111. (https://doi.org/10.1152/ ajpregu.1998.275.1.R105)

Baura GD, Foster DM, Porte D Jr, Kahn SE, Bergman RN, Cobelli C \& Schwartz MW 1993 Saturable transport of insulin from plasma into the central nervous system of dogs in vivo. A mechanism for regulated insulin delivery to the brain. Journal of Clinical Investigation 92 1824-1830. (https://doi.org/10.1172/JCI116773)

Beck-Nielsen H, De Pirro R \& Pedersen O 1980 Prednisone increases the number of insulin receptors on monocytes from normal subjects. Journal of Clinical Endocrinology and Metabolism 50 1-4. (https://doi. org/10.1210/jcem-50-1-1)

Belgardt BF, Mauer J \& Brüning JC 2010 Novel roles for JNK1 in metabolism. Aging 2 621-626. (https://doi.org/10.18632/ aging.100192)

Benoit SC, Air EL, Coolen LM, Strauss R, Jackman A, Clegg DJ, Seeley RJ $\&$ Woods SC 2002 The catabolic action of insulin in the brain is mediated by melanocortins. Journal of Neuroscience 22 9048-9052.

Brief DJ \& Davis JD 1984 Reduction of food intake and body weight by chronic intraventricular insulin infusion. Brain Research Bulletin 12 571-575. (https://doi.org/10.1016/0361-9230(84)90174-6)

Caro JF \& Amatruda JM 1982 Glucocorticoid-induced insulin resistance: the importance of postbinding events in the regulation of insulin binding, action, and degradation in freshly isolated and primary cultures of rat hepatocytes. Journal of Clinical Investigation 69 866-875. (https://doi.org/10.1172/JCI110526)

Castro M, Figueiredo F \& Moreira AC 1995 Time-course of hypothalamic $\mathrm{CRH}$ and pituitary ACTH contents, and pituitary responsiveness to CRH stimulation after bilateral adrenalectomy. Hormone and Metabolic Research 27 10-15. (https://doi.org/10.1055/s-2007-979897)

Chan O, Inouye K, Akirav E, Park E, Riddell MC, Vranic M \& Matthews SG 2005 Insulin alone increases hypothalamo-pituitaryadrenal activity, and diabetes lowers peak stress responses. Endocrinology 146 1382-1390. (https://doi.org/10.1210/en.2004-0607)

Chavez M, Seeley RJ, Green PK, Wilkinson CW, Schwartz MW \& Woods SC 1997 Adrenalectomy increases sensitivity to central insulin. Physiology and Behavior 62 631-634. (https://doi.org/10.1016/S0031-9384(97)00188-1)

De Meyts P 2016 The insulin receptor and its signal transduction network. In Endotext. Eds LJ De Groot, Chrousos G, Dungan K, et al. South Dartmouth, MA, USA: MDText.com, Inc. (available at: https:// www.ncbi.nlm.nih.gov/books/NBK378978/) 
Desbuquois B, Tozzo E, Collinet M, Lopez S, Bortoli S \& Amessou M 1993 Regulation of insulin receptor expression and its gene. Annales d'Endocrinologie 54 373-384.

Devenport LD \& Devenport JA 1982 The effects of adrenal hormones on brain and body size. Physiological Psychology 10 399-404. (https://doi org/10.3758/BF03332971)

Devenport LD, Torres A \& Murray CG 1983 Effects of aldosterone and deoxycorticosterone on food intake and body weight. Behavioral Neuroscience 97 667-669. (https://doi.org/10.1037/0735-7044.97.4.667)

Devenport LD, Goodwin KG \& Hopkins PM 1985 Continuous infusion of aldosterone: correlates of body weight gain. Pharmacology, Biochemistry and Behavior 22 707-709. (https://doi.org/10.1016/00913057(85)90517-9)

Forkwa TK, Neumann ID, Tamm ER, Ohlmann A \& Reber SO 2014 Short-term psychosocial stress protects photoreceptors from damage via corticosterone-mediated activation of the AKT pathway. Experimental Neurology 252 28-36. (https://doi.org/10.1016/j. expneurol.2013.11.016)

Freedman MR, Castonguay TW \& Stern JS 1985 Effect of adrenalectomy and corticosterone replacement on meal patterns of Zucker rats. American Journal of Physiology 249 R584-R594. (https://doi. org/10.1152/ajpregu.1985.249.5.R584)

Gemmill ME, Eskay RL, Hall NL, Douglass LW \& Castonguay TW 2003 Leptin suppresses food intake and body weight in corticosteronereplaced adrenalectomized rats. Journal of Nutrition 133 504-509. (https://doi.org/10.1093/jn/133.2.504)

Germano CM, de Castro M, Rorato R, Laguna MT, Antunes-Rodrigues J, Elias CF \& Elias LL 2007 Time course effects of adrenalectomy and food intake on cocaine- and amphetamine-regulated transcript expression in the hypothalamus. Brain Research 1166 55-64. (https:// doi.org/10.1016/j.brainres.2007.05.077)

Germano CM, Castro Md, Rorato R, Costa DB, Antunes-Rodrigues J, Elias CF \& Elias LL 2008 Downregulation of melanocortin-4 receptor during refeeding and its modulation by adrenalectomy in rats. Hormone and Metabolic Research 40 842-847. (https://doi. org/10.1055/s-0028-1086024)

Haluzik M, Dietz KR, Kim JK, Marcus-Samuels B, Shulman GI, Gavrilova O \& Reitman ML 2002 Adrenalectomy improves diabetes in A-ZIP/F-1 lipoatrophic mice by increasing both liver and muscle insulin sensitivity. Diabetes 51 2113-2118. (https://doi.org/10.2337/ diabetes.51.7.2113)

Honda K, Kamisoyama H, Saneyasu T, Sugahara K \& Hasegawa S 2007 Central administration of insulin suppresses food intake in chicks. Neuroscience Letters 423 153-157. (https://doi.org/10.1016/j. neulet.2007.07.004)

Iwama N, Nomura M, Kajimoto Y, Imano E, Kubota M, Watarai T, Kawamori R, Shichiri M \& Kamada T 1987 Effect of dexamethasone on the synthesis and degradation of insulin receptor mRNA in cultured IM-9 cells. Diabetologia 30 899-901. (https://doi.org/10.1007/ BF00274801)

Li HY, Hwang HW \& Hu YH 2002 Functional characterizations of cocaine- and amphetamine-regulated transcript mRNAexpression in rat hypothalamus. Neuroscience Letters 323 203-206. (https://doi. org/10.1016/S0304-3940(02)00151-9)

Livak KJ \& Schmittgen TD 2001 Analysis of relative gene expression data using real-time quantitative PCR and the 2(-delta delta C(T)) method. Methods 25 402-408. (https://doi.org/10.1006/meth.2001.1262)

Long W, Barrett EJ, Wei L \& Liu Z 2003 Adrenalectomy enhances the insulin sensitivity of muscle protein synthesis. American Journal of Physiology: Endocrinology and Metabolism 284 E102-E109. (https://doi. org/10.1152/ajpendo.00028.2002)

Madiehe AM, Lin L, White C, Braymer HD, Bray GA \& York DA 2001 Constitutive activation of STAT-3 and downregulation of SOCS-3 expression induced by adrenalectomy. American Journal of Physiology: Regulatory, Integrative and Comparative Physiology 281 R2048-R2058. (https://doi.org/10.1152/ajpregu.2001.281.6.R2048)
Mamula PW, McDonald AR, Brunetti A, Okabayashi Y, Wong KY, Maddux BA, Logsdon C \& Goldfine ID 1990 Regulating insulinreceptor-gene expression by differentiation and hormones. Diabetes Care 13 288-301. (https://doi.org/10.2337/diacare.13.3.288)

Mayer CM \& Belsham DD 2009 Insulin directly regulates NPY and AgRP gene expression via the MAPK MEK/ERK signal transduction pathway in mHypoE-46 hypothalamic neurons. Molecular and Cellular Endocrinology 307 99-108. (https://doi.org/10.1016/j. mce.2009.02.031)

McDonald AR, Maddux BA, Okabayashi Y, Wong KY, Hawley DM, Logsdon CD \& Goldfine ID 1987 Regulation of insulin-receptor mRNA levels by glucocorticoids. Diabetes 36 779-781. (https://doi. org/10.2337/diab.36.6.779)

McGowan MK, Andrews KM, Kelly J \& Grossman SP 1990 Effects of chronic intrahypothalamic infusion of insulin on food intake and diurnal meal patterning in the rat. Behavioral Neuroscience $\mathbf{1 0 4}$ 373-385. (https://doi.org/10.1037/0735-7044.104.2.373)

Morton GJ, Cummings DE, Baskin DG, Barsh GS \& Schwartz MW 2006 Central nervous system control of food intake and body weight. Nature 443 289-295. (https://doi.org/10.1038/nature05026)

Motta K, Barbosa AM, Bobinski F, Boschero AC \& Rafacho A 2015 JNK and IKK $\beta$ phosphorylation is reduced by glucocorticoids in adipose tissue from insulin-resistant rats. Journal of Steroid Biochemistry and Molecular Biology 145 1-12. (https://doi.org/10.1016/j. jsbmb.2014.09.024)

Niswender KD, Morrison CD, Clegg DJ, Olson R, Baskin DG, Myers MG Jr, Seeley RJ \& Schwartz MW 2003 Insulin activation of phosphatidylinositol 3-kinase in the hypothalamic arcuate nucleus: a key mediator of insulin-induced anorexia. Diabetes 52 227-231. (https://doi.org/10.2337/diabetes.52.2.227)

Niswender KD \& Schwartz MW 2003 Insulin and leptin revisited: adiposity signals with overlapping physiological and intracellular signaling capabilities. Frontiers in Neuroendocrinology 24 1-10. (https:// doi.org/10.1016/S0091-3022(02)00105-X)

Oelkers W 1996 Adrenal insufficiency. New England Journal of Medicine 335 1206-1212. (doi:10.1056/NEJM199610173351607)

Olefsky JM 1975 Effect of dexamethasone on insulin binding, glucose transport, and glucose oxidation of isolated rat adipocytes. Journal of Clinical Investigation 56 1499-1508. (https://doi.org/10.1172/ JCI108231)

Panchal SK, Poudyal H, Iyer A, Nazer R, Alam MA, Diwan V, Kauter K, Sernia C, Campbell F, Ward L, et al. 2011 High-carbohydrate high-fat diet-induced metabolic syndrome and cardiovascular remodeling in rats. Journal of Cardiovascular Pharmacology 57 51-64. (https://doi. org/10.1097/FJC.0b013e31821b1379)

Pardini AW, Nguyen HT, Figlewicz DP, Baskin DG, Williams DL, Kim F \& Schwartz MW 2006 Distribution of insulin receptor substrate-2 in brain areas involved in energy homeostasis. Brain Research 1112 169-178. (https://doi.org/10.1016/j.brainres.2006.06.109)

Paxinos G \& Watson C 1997 The Rat Brain in Stereotaxic Coordinates. San Diego, CA, USA: Academic Press.

Peiser C, McGregor GP \& Lang RE 2000 Leptin receptor expression and suppressor of cytokine signaling transcript levels in high-fat-fed rats. Life Sciences 67 2971-2981. (https://doi.org/10.1016/S00243205(00)00884-5)

Plum L, Schubert M \& Brüning JC 2005 The role of insulin receptor signaling in the brain. Trends in Endocrinology and Metabolism 16 59-65. (https://doi.org/10.1016/j.tem.2005.01.008)

Raboin SJ, Gulley S, Henley SC, Chang WC, Esdaile AR, Jackson CA \& Sayegh AI 2006 Effect of adrenalectomy on cholecystokinin-8induced Foslike immunoreactivity in myenteric nervous and the dorsal vagal complex in rats. American Journal of Veterinary Research 67 1552-1556. (https://doi.org/10.2460/ajvr.67.9.1552)

Rorato R, Borges BC, Uchoa ET, Antunes-Rodrigues J, Elias CF \& Elias LLK 2017 LPS-induced low-grade inflammation increases hypothalamic JNK expression and causes central insulin resistance irrespective of https://joe.bioscientifica.com

https://doi.org/10.1530/JOE-19-0217 (c) 2019 Society for Endocrinology Published by Bioscientifica Ltd. Printed in Great Britain 
body weight changes. International Journal of Molecular Sciences $\mathbf{1 8}$ 1431. (https://doi.org/10.3390/ijms18071431)

Savontaus E, Conwell IM \& Wardlaw SL 2002 Effects of adrenalectomy on AGRP, POMC, NPY and CART gene expression in the basal hypothalamus of fed and fasted rats. Brain Research 958 130-138. (https://doi.org/10.1016/S0006-8993(02)03674-0)

Schwartz MW, Marks JL, Sipols AJ, Baskin DG, Woods SC, Kahn SE \& Porte D Jr 1991 Central insulin administration reduces neuropeptide Y mRNA expression in the arcuate nucleus of food-deprived lean ( $\mathrm{Fa} /$ Fa) but not obese (fa/fa) Zucker rats. Endocrinology 128 2645-2647. (https://doi.org/10.1210/endo-128-5-2645)

Schwartz MW, Sipols AJ, Marks JL, Sanacora G, White JD, Scheurink A, Kahn SE, Baskin DG, Woods SC \& Figlewicz DP 1992 Inhibition of hypothalamic neuropeptide Y gene expression by insulin. Endocrinology 130 3608-3616. (https://doi.org/10.1210/ endo.130.6.1597158)

Tempel DL \& Leibowitz SF 1989 PVN steroid implants: effect on feeding patterns and macronutrient selection. Brain Research Bulletin $\mathbf{2 3}$ 553-560. (https://doi.org/10.1016/0361-9230(89)90200-1)

Trayhurn P, Thomas ME, Duncan JS \& Rayner DV 1995 Effects of fasting and refeeding on ob gene expression in white adipose tissue of lean and obese (ob/ob) mice. FEBS Letters 368 488-490. (https://doi. org/10.1016/0014-5793(95)00719-P)

Uchoa ET, Sabino HA, Ruginsk SG, Antunes-Rodrigues J \& Elias LL 2009a Hypophagia induced by glucocorticoid deficiency is associated with an increased activation of satiety-related responses. Journal of Applied Physiology 106 596-604. (https://doi.org/10.1152/ japplphysiol.90865.2008)

Uchoa ET, Mendes da Silva LE, de Castro M, Antunes-Rodrigues J \& Elias LL 2009b Hypothalamic oxytocin neurons modulate hypophagic effect induced by adrenalectomy. Hormones and Behavior 56 532-538. (https://doi.org/10.1016/j.yhbeh.2009.09.007)

Uchoa ET, da Silva LE, de Castro M, Antunes-Rodrigues J \& Elias LL 2010 Corticotrophin-releasing factor mediates hypophagia after adrenalectomy, increasing meal-related satiety responses. Hormones and Behavior 58 714-719. (https://doi.org/10.1016/j.yhbeh.2010.07.003)

Uchoa ET, Silva LE, de Castro M, Antunes-Rodrigues J \& Elias LL 2012 Glucocorticoids are required for meal-induced changes in the expression of hypothalamic neuropeptides. Neuropeptides 46 119-124. (https://doi.org/10.1016/j.npep.2012.02.002)

Unger J, McNeill TH, Moxley RT 3rd, White M, Moss A \& Livingston JN 1989 Distribution of insulin receptor-like immunoreactivity in the rat forebrain. Neuroscience 31 143-157. (https://doi.org/10.1016/03064522(89)90036-5)

van Houten M, Posner BI, Kopriwa BM \& Brawer JR 1980 Insulin binding sites localized to nerve terminals in rat median eminence and arcuate nucleus. Science 207 1081-1083. (https://doi.org/10.1126/ science.6986652)

Vogt MC \& Brüning JC 2013 CNS insulin signaling in the control of energy homeostasis and glucose metabolism from embryo to old age. Trends in Endocrinology and Metabolism 24 76-84. (https://doi. org/10.1016/j.tem.2012.11.004)

Wang J \& Leibowitz KL 1997 Central insulin inhibits hypothalamic galanin and neuropeptide $\mathrm{Y}$ gene expression and peptide release in intact rats. Brain Research 777 231-236. (https://doi.org/10.1016/ S0006-8993(97)00963-3)

Weinstein SP, Paquin T, Pritsker A \& Haber RS 1995 Glucocorticoidinduced insulin resistance: dexamethasone inhibits the activation of glucose transport in rat skeletal muscle by both insulin- and noninsulin-related stimuli. Diabetes 44 441-445. (https://doi.org/10.2337/ diab.44.4.441)

Werther GA, Hogg A, Oldfield BJ, McKinley MJ, Figdor R, Allen AM \& Mendelsohn FA 1987 Localization and characterization of insulin receptors in rat brain and pituitary gland using in vitro autoradiography and computerized densitometry. Endocrinology 121 1562-1570. (https://doi.org/10.1210/endo-121-4-1562)

Xu E, Schwab M \& Marette A 2014 Role of protein tyrosine phosphatases in the modulation of insulin signaling and their implication in the pathogenesis of obesity-linked insulin resistance. Reviews in Endocrine and Metabolic Disorders 15 79-97. (https://doi.org/10.1007/s11154013-9282-4)

Yang MJ, Wang F, Wang JH, Wu WN, Hu ZL, Cheng J, Yu DF, Long LH, $\mathrm{Fu} \mathrm{H}$, Xie N, et al. 2010 PI3K integrates the effects of insulin and leptin on large-conductance Ca2+-activated $\mathrm{K}+$ channels in neuropeptide $\mathrm{Y}$ neurons of the hypothalamic arcuate nucleus. American Journal of Physiology: Endocrinology and Metabolism 298 E193-E201. (https://doi.org/10.1152/ajpendo.00155.2009)

Zakrzewska KE, Cusin I, Sainsbury A, Rohner-Jeanrenaud F \& Jeanrenaud B 1997 Glucocorticoids as counterregulatory hormones of leptin: toward an understanding of leptin resistance. Diabetes $\mathbf{4 6}$ 717-719. (https://doi.org/10.2337/diab.46.4.717)

Zhang ZY, Dodd GT \& Tiganis T 2015 Protein tyrosine phosphatases in hypothalamic insulin and leptin signaling. Trends in Pharmacological Sciences 36 661-674. (https://doi.org/10.1016/j.tips.2015.07.003) https://joe.bioscientifica.com https://doi.org/10.1530/JOE-19-0217 (c) 2019 Society for Endocrinology Published by Bioscientifica Ltd.
Received in final form 5 June 2019

Accepted 10 June 2019

Accepted Preprint published online 10 June 2019 